\title{
Investigation and Analysis on Current Situation of Football Training in Colleges of Huangshi City of Hubei
}

\author{
Jia You \\ School of Physical Education \\ Hubei University of Education \\ Wuhan, China 430205
}

\begin{abstract}
With continuously in-depth reform of football teaching, the proportion of football in physical education increases ceaselessly in Chinese universities. Football is participatory and antagonistic, recreational and interesting and can promote students' team spirit, physical quality, sports skills and psychological endurance in physical education of universities, in order to improve college students' comprehensive quality. Current situation of football course in colleges of Huangshi and teachers' professional level are researched to provide strategies for better and more scientific football training in colleges of Huangshi city.
\end{abstract}

Keywords-football; current situation; investigation; analysis

\section{INTRODUCTION}

With rapid economic and social development of China, people's living standard improves greatly. More and more people realize physical education promotes fitness and participate in it. In recent years, football gets rapid popularization and development in our country. An increasing number of people participate in it. Football match plays distinctly important role in implementing national fitness program and promoting football popularization and socialization.

Colleges in Huangshi city carry out football teaching under social environment. Football is easy for college students to learn and has far-reaching significance on developing students' habits of lifelong physical exercise and implementing "national fitness program" and cultivating patriotic talents. Current situation of football training in colleges of Huangshi city and whether teachers' professional level can meet demands of implementing football are researched, in order to provide strategies for better and more scientific football training.

\section{Research OBJects And Methods}

\section{A. Research Objects}

Students majoring in football in Hubei Normal University, Hubei Polytechnic University, the School of Art and Science of Hubei Normal University, Hubei Engineering Institute, Huangshi Junior College

\section{B. Research Methods}

\section{1) Literature review method}

Look up CNKI (China National Knowledge Infrastructure), China Journal Net and Wanfang Database, and refer to academic works and literature related to the history of football and introduction to football.

\section{2) Questionnaire survey}

Do questionnaire survey on students majoring in football in Hubei Normal University, Hubei Polytechnic University, the School of Art and Science of Hubei Normal University, Hubei Engineering Institute, Huangshi Junior College. 500 questionnaires are distributed to the five schools with 100 questionnaires for each school. It is collected actively and seriously, with 500 valid questionnaires collected and effective rate of 100 percent.

\section{3) Mathematical statistics}

Excel is used to carry out logical analysis on questionnaires. Microsoft Office Excel 2007 is used to sort and analyze the data and deduce its results.

\section{RESULT AND ANALYSIS}

\section{A. Teaching Status of Football Course in Colleges of Huangshi City \\ 1) Knowledge taught by football teachers and analysis}

According to the investigation on football course of colleges of Huangshi city, football teaching includes theory and practice. Theoretical teaching contents include theories of football tactics and basic knowledge, fundamentals of exercise and fitness and exercise methods, prevention and removal of sport injury, knowledge on health maintenance related to physical education and exercise prescription. Football teaching in universities makes the best of flexible, practical and pertinent theoretical teaching. The practice centers on football training and competition and highlights learning and exercise of football skills, as shown in "Table I". 
TABLE I. CONTENTS OF FOOTBALl TEACHING IN COLLEGES OF HUANGSHI CITY AND TEACHING ARRANGEMENTS (HUBEI NORMAL UNIVERSITY IS TAKEN AS THE RESPONDENT.)

\begin{tabular}{ll}
\hline \multicolumn{1}{c}{ Teaching contents } & $\begin{array}{c}\text { Teaching } \\
\text { period }\end{array}$ \\
A. Theoretical knowledge & 1 \\
1. Origin and development of football & \\
2. Transmission and development of football in China & 1 \\
3. Competition methods, movement features and & \\
functions of football & 10 \\
B. Basic skills & 2 \\
1. Ball familiarity & 1 \\
2. Kick the ball & 2 \\
3. Stop the ball & 1 \\
4. Dribbling & 2 \\
5. Throw-in & 1 \\
6. Header & 1 \\
7. Forage for the ball & 2 \\
C. Basic tactics & 1 \\
1. "Wall pass" collaboration & 1 \\
2. Support and positioning & \\
3.Positioning-choosing and marking & \\
4.Learning of rules and code of arbitrage & 3 \\
D. Physical quality & 1 \\
1. General physical quality & 2 \\
2. Special physical quality & \\
\hline \multicolumn{2}{c}{ 2) Site facilities and equipment for students to learn } \\
football
\end{tabular}

"Table II" indicates sports places in colleges investigated in Huangshi city focus on school stadium, playground, classroom and clubs.

TABLE II. STATISTICAL ANALYSIS ON SiTES OF FOOTBALL IN SOME COLlEGES OF HuANGSHI CiTY

\begin{tabular}{lllll}
\hline & $\begin{array}{c}\text { School } \\
\text { stadium }\end{array}$ & Playground & $\begin{array}{l}\text { Class } \\
\text { room }\end{array}$ & Club \\
\hline $\begin{array}{lllll}\text { Hubei Normal University } \\
\text { Hubei Polytechnic }\end{array}$ & $\sqrt{ }$ & $\sqrt{ }$ & $\sqrt{ }$ & $\sqrt{ }$ \\
$\begin{array}{l}\text { University } \\
\text { School of Art and Science }\end{array}$ & & $\sqrt{ }$ & $\sqrt{ }$ & \\
of Hubei Normal & $\sqrt{ }$ & & & $\sqrt{ }$ \\
University & & & & \\
$\begin{array}{l}\text { Hubei Engineering Institute } \\
\text { Huangshi Junior College }\end{array}$ & $\sqrt{ }$ & $\sqrt{ }$ & $\sqrt{ }$ & \\
\hline
\end{tabular}

"Table III" indicates students mainly use equipment purchased by the school, including 356 people that account for 71.2 percent. 78 people purchase by themselves and account for 15.6 percent. 66 people have other selections and account for 13.2 percent. The investigation shows other selections mainly include borrowing from other students.

TABLE III. STATISTICAL ANALySIS ON APPLICATION OF FoOTBALL EQUIPMENT IN SOME COLLEGES OF HUANGSHI CITY

\begin{tabular}{llll}
\hline & \multicolumn{1}{c}{$\begin{array}{c}\text { School } \\
\text { equipment }\end{array}$} & $\begin{array}{c}\text { Purchased by } \\
\text { themselves }\end{array}$ & Other \\
\hline Number of people & 356 & 78 & 66 \\
Proportion (\%) & 71.2 & 15.6 & 13.2 \\
\hline
\end{tabular}

3) Evaluation and analysis of students on football teaching

"Table IV" indicates 23.6 percent of students in some colleges of Huangshi city completely adapt to football teaching arrangement at present; 58 percent of students basically adapt to football teaching at present; only 18.4 percent of students fail to adapt to the teaching arrangement at present. Most students in some colleges of Huangshi city can accept the difficulty of football course, and the difficulty can be increased further.

TABLE IV. INVESTIGATION AND ANALYSIS ON ADAPTATION TO FOOTBALL TEACHING IN SOME COLLEGES OF HUANGSHI CITY

\begin{tabular}{llll}
\hline & $\begin{array}{c}\text { Adapt } \\
\text { very well }\end{array}$ & $\begin{array}{c}\text { Basically } \\
\text { adapt }\end{array}$ & $\begin{array}{c}\text { Cannot } \\
\text { adapt }\end{array}$ \\
\hline Hubei Normal University & 25 & 61 & 14 \\
Hubei Polytechnic University & 24 & 55 & 21 \\
School of Art and Science of & 19 & 61 & 20 \\
Hubei Normal University & 35 & 49 & 16 \\
Hubei Engineering Institute & 15 & 64 & 21 \\
Huangshi Junior College & 118 & 290 & 92 \\
Total & & & \\
\hline
\end{tabular}

4) Requirements for students' physical quality

Participants of football must have good physical quality, in order to actively and positively attend football training and meet requirements of skills and tactics in football competitions. Physical quality embodies athletic ability through human figure and physical agility to achieve results. The absence of good physical quality cannot meet demands of tactic development. Therefore, in routine training, college students must scientifically formulate methods to train physical quality according to their physical conditions.

TABLE V. INVESTIGATION AND ANALYSIS ON PHYSICAL CONDITIONS of STUDENTS IN SOME COLLEGES OF HUANGSHI CITY AFTER PARTICIPATING IN FOOTBALL COMPETITIONS

\begin{tabular}{|c|c|c|c|}
\hline & $\begin{array}{l}\text { Full of } \\
\text { physical } \\
\text { strength }\end{array}$ & $\begin{array}{c}\text { Basically } \\
\text { adapt }\end{array}$ & $\begin{array}{c}\text { Physical } \\
\text { exhaustion }\end{array}$ \\
\hline Hubei Normal University & 11 & 48 & 41 \\
\hline $\begin{array}{l}\text { Hubei } \\
\text { University }\end{array}$ & 13 & 51 & 36 \\
\hline $\begin{array}{l}\text { School of Art and } \\
\text { Science of Hubei Normal } \\
\text { University }\end{array}$ & 23 & 58 & 19 \\
\hline $\begin{array}{l}\text { Hubei } \quad \text { Engineering } \\
\text { Institute }\end{array}$ & 21 & 47 & 32 \\
\hline Huangshi Junior College & 18 & 59 & 23 \\
\hline Total & 86 & 263 & 151 \\
\hline
\end{tabular}

The investigation indicates in competition, athletes often have slow movement in later period of competitions because of poor special endurance. Among the five schools investigated, 17.2 percent of students feel full of physical strength; 52.6 percent can adapt basically; 30.2 percent feel physical exhaustion. Poor physical quality influences competition results even the victory or defeat of competition. Therefore, football players must have good physical quality and endurance.

\section{B. Participation of College Students in Football}

1) Recognition and learning motivation of students on football.

According to table 6, among the five schools, 46.6 percent of students know football very well; 32.4 percent basically understand; 21.2 percent do not understand. It indicates football is popular in colleges, but because of insufficient popularization, not too many students can basically understand it. Most students only know about some superficial football 
knowledge. Therefore, propaganda and guidance on football must be strengthened.

TABLE VI. StatisticAl TABLE ABOUt ReCOGNition OF COLLEGE STUDENTS IN HUANGSHI CITY ON FOOTBALL AND ITS RULES

\begin{tabular}{llll}
\hline & $\begin{array}{c}\text { Know very } \\
\text { well }\end{array}$ & $\begin{array}{c}\text { Basically } \\
\text { understand }\end{array}$ & $\begin{array}{c}\text { Do not } \\
\text { understand }\end{array}$ \\
\hline $\begin{array}{l}\text { Hubei Normal University } \\
\text { Hubei Polytechnic University }\end{array}$ & 32 & 31 & 21 \\
$\begin{array}{l}\text { School of Art and Science of } \\
\text { Hubei Normal University }\end{array}$ & 49 & 32 & 22 \\
$\begin{array}{l}\text { Hubei Engineering Institute } \\
\text { Huangshi Junior College }\end{array}$ & 51 & 28 & 18 \\
Total & 52 & 36 & 21 \\
\hline
\end{tabular}

"Table VII" indicates among colleges investigated in Huangshi city, 50.2 percent of students aim at exercise training; 9.6 percent aim at social contact; 9 percent are in company with others; 31.2 percent aim at obtaining credits. The football training in colleges of Huangshi city focuses on exercise training.

TABLE VII. INVESTIGATION AND ANALYSIS ON LEARNING MOTIVATION OF FOOTBALl LEARNERS IN COLLEGES OF HUANGGANG CITY

\begin{tabular}{|c|c|c|c|c|}
\hline & $\begin{array}{c}\text { Exercise } \\
\text { training }\end{array}$ & $\begin{array}{c}\text { Social } \\
\text { contact }\end{array}$ & $\begin{array}{c}\text { Accompa } \\
\text { nying }\end{array}$ & $\begin{array}{c}\text { Credit } \\
\text { requirement }\end{array}$ \\
\hline $\begin{array}{l}\text { Number of } \\
\text { people }\end{array}$ & 251 & 48 & 45 & 156 \\
\hline Proportion & $50.2 \%$ & $9.6 \%$ & $9 \%$ & $31.2 \%$ \\
\hline
\end{tabular}

2) Students' evaluation on teaching elements of football course

Influenced by many elements, football teaching aims at improving students' football level. Except for physical condition of football participants, it is influenced by many subjective and objective factors. High quality football training relates to links, elements and processes involved. Teaching elements include: first, basic knowledge of football, special training rules of football; second, students' understanding of football skills to highlight individual difference; third, football teaching objectives; fourth, systematic teaching plan; fifth, suitable training load.

\section{3) Dynamic development of students' football learning}

According to the investigation on football training in some colleges of Huangshi city, colleges depend on classroom teaching that influences sustainable development and popularization of football. Although some students have learning interests, they are restricted by many factors such as the absence of sufficient training place, sports equipment, football facilities, opening hours of stadium and operating efficiency. It causes adverse effects on dynamic development of football.

\section{Countermeasures for Football Development in Colleges of Huangshi City}

\section{1) Develop correct fit-keeping concept of students}

College students are energetic and have spare time and should develop good fit-keeping concept. Sports meet demands of physiological development and psychological quality and social adaptation ability, and refer to the inevitable choice to promote their integrated development. College students' interests in participating in physical exercise relate to their purposes of participation and self-condition.

Students can establish good fit-keeping concept through football. In the stimulation of students' interests in football, teachers must pay attention to normalization of actions, because football needs the participation of body parts. Error actions will lead to uncoordinated body movement of college students, so ideal fit-keeping purpose cannot be achieved. Students can train step by step and persevere. Apposite football can make college students' exercise and enrich campus culture.

\section{2) Intensify scientific propaganda}

Colleges of Huangshi city must let more students play football through social propaganda. People can adjust amount of training in playing football, which is interesting suitable for college students and can exercise all body parts.

3) Increase the number of professional football coach and improve quality

According to the investigation, football has solid mass base in Huangshi city. More professional football coaches are required for better football training in colleges of Huangshi city. However, there is basically no professional football coach in football stadium of Huangshi city, leading to the absence of scientific theoretical fit-keeping knowledge. Football coaches in some stadiums guide through experience instead of scientific fit-keeping guidance.

Sports management departments of Huangshi city should bring in public welfare people and more football professionals to guide football in colleges of Huangshi city.

\section{CONCLUSION}

\section{A. School Leaders Pay Insufficient Attentions and Coaches Have deficient Training.}

At present, training classes of excellent football coaches in Huangshi city haven't been held or no attentions are paid to it. It lacks funding support and equipment support. Besides, instructors who ardently love football have retired, so the football training in Huangshi city lacks leaders. Young instructors lack work experience and dedication, directly influencing football training in Huangshi city.

\section{B. Stadium Influence}

Limited football stadium is one of the reasons influencing football training in colleges of Huangshi city. In recent years, an increasing number of people learn football in colleges of Huangshi city, but the limited stadium directly influences football training. The absence of football facilities and apposite stadium directly restrict the development of football training in colleges of Huangshi city.

\section{Lack Corresponding Competition System}

Football training in colleges of Huangshi city depends on students' conscious hobby instead of special competition 
systems. Competition is important means for football development. Reasonable football competition systems are of vital importance for football development in Huangshi city. There is only one football competition at college level in Huangshi city, which directly makes the football training lack corresponding motivation measures and fail to improve students' interests in playing football.

\section{REFERENCES}

[1] Zhang Qidi. Teaching Research and Practice of Football Elective Course in Universities [J], Hebei Normal University, 2012 (11: 234-237)

[2] Wang Lijun. Research on Football Training on Campus of Universities in Gansu Province and Development Countermeasures [J], Northwest Normal University, 2013(18: 52-58)

[3] Li Xingshan. Research on Current Situation of Football Training in Shandong Province and Development Countermeasures [J], Shandong Normal University, 2014 (13: 114-117)

[4] Ma Liangji. Research and Analysis on Factors Influencing the Development of Football Culture in Universities of Wuhan City [J], Wuhan Institute of Physical Education, 2013

[5] Yang Xin. Investigation and Analysis on Current Situation of Football Training in Universities of Urumqi [D], Xinjiang Normal University, 2014

[6] Zhang Hongrui. Analysis on Importance of Sustainable Development of Campus Football on Chinese Football [J], Shandong University, 2013(11: 12-16)

[7] Zheng Xinhui. Research on Establishment of College Football League under the Background of "Campus Football" [D], East China Jiaotong University, 2013 